\title{
APAKAH UKURAN PERUSAHAAN DAN KINERJA KEUANGAN MEMPENGARUHI PERUSAHAAN DALAM MENGUNGKAPKAN SUSTAINABILITY REPORT?
}

\section{DO SIZE OF COMPANY AND FINANCIAL PERFORMANCE INFLUENCE COMPANY TO DISCLOSE SUSTAINABILITY REPORT?}

\author{
Dwi Indah Lestari ${ }^{1}$, Merta Noer Vadila ${ }^{2}$ \\ Universitas Jenderal Achmad Yani ${ }^{1,2}$ \\ dwi.lestari@,lecture@unjani.ac.id ${ }^{1}$
}

\begin{abstract}
One way to increase corporate awareness and responsibility for the environment can be done through Sustainability reports. The purpose of this study is to analyze the effect of company size and financial performance on the disclosure of Sustainability Reports on non-financial sector companies listed on the Stock Exchange in 2017-2018 both partially and simultaneously. Company size is measured using total assets while financial performance is measured using the ratio of Return on Assets. This study uses secondary data obtained from the Indonesia Stock Exchange (IDX) and uses an associative descriptive method with a quantitative approach. This research uses purposive sampling method. The results of this study indicate that both partially and simultaneously, company size and financial performance do not significantly influence the disclosure of Sustainability Report elements.
\end{abstract}

Keywords : Sustainability Report, Companies'size, Financial Performance

\begin{abstract}
ABSTRAK
Salah satu cara dalam meningkatkan kesadaran dan tanggung jawab perusahaan terhadap lingkungan dapat dilakukan melalui Sustainability report atau laporan berkelanjutan. Tujuan penelitian ini adalah untuk menganalisa pengaruh ukuran perusahaan dan kinerja keuangan terhadap pengungkapan Sustainability Report pada perusahaan sektor non keuangan yang terdaftar di BEI pada tahun 2017-2018 baik secara parsial maupun secara simultan. Ukuran perusahaan diukur dengan menggunakan total aset sedangkan kinerja keuangan diukur dengan menggunakan rasio Return on Asset. Penelitian ini menggunakan data sekunder yang diperoleh dari Bursa Efek Indonesia (IDX) dan menggunakan metode deskriptif asosiatif dengan pendekatan kuantitatif. Penelitian ini menggunakan metode purposive sampling. Hasil dari penelitian ini menunjukan bahwa baik secara parsial maupun simultan, ukuran perusahaan dan kinerja keuangan tidak berpengaruh signifikan terhadap pengungkapan elemen Sustainability Report.
\end{abstract}

Keywords : Sustainability Report, Ukuran Perusahaan, Kinerja Keuangan

\section{PENDAHULUAN}

Global warming dan climate change merupakan masalah yang tengah disoroti oleh banyak pihak di seluruh dunia, khususnya pemerintah dan perusahaan. Saat ini, tidak seluruh aktivitas perusahaan berdampak baik pada lingkungan. Aturan pemerintah, 
terutama di Negara berkembang, belum dapat menjamin seluruh aktivitas perusahaan berdampak baik pada kondisi sosial dan lingkungan.

Salah satu cara dalam meningkatkan kesadaran dan tanggung jawab perusahaan terhadap lingkungan dapat dilakukan melalui Sustainability report atau laporan berkelanjutan. Global Reporting Initiative (GRI) merupakan suatu organisasi independen yang memperkenalkan konsep The GRI Sustainability Reporting Standards (GRI Standards) pertama kali di tahun 1997 (Global Reporting Initiative, 2019). GRI mendefinisikan Sustainability Reporting sebagai laporan yang disampaikan oleh perusahan mengenai kondisi ekonomi, lingkungan dan dampak sosial yang dipengaruhi oleh aktivitas operasional perusahaan.

Konsep dalam Pedoman GRI Standards terbagi kedalam dua standar yaitu standar universal dan standar topik spesifik. Konsep GRI standards terus berkembang, saat ini ada 77 item pengungkapan dalam Sustainability Report, yang terdiri atas 3 topik, meliputi topik ekonomi, lingkungan dan social.

Sustainability Report dapat dijadikan sebagai suatu mekanisme yang memaksa perusahaan untuk melakukan kegiatan operasionalnya secara bertanggung jawab sehingga mampu membuktikan bahwa perusahaan akuntabel. Dalam jangka waktu 20 tahun terakhir, aktivitas pengungkapan Sustainability Report semakin banyak dilakukan oleh perusahaan di seluruh dunia (PérezLópez, Moreno-Romero and Barkemeyer, 2015).

Menurut Gray (2006) salah satu ciri dari perusahaan yang akuntabel adalah perusahaan tersebut menyediakan informasi kepada stakeholder, baik berupa informasi yang bersifat keuangan maupun nonkeuangan. Saat ini perusahaan hanya mengutamakan informasi yang bersifat keuangan, lewat financial statement meskipun perusahaan menyadari bahwa akuntansi keuangan tradisional tidak dapat memenuhi kebutuhan informasi para pengguna laporan keuangan (Farneti \& Guthrie, 2009). Sayangnya sampai saat ini, pemerintah Indonesia belum mewajibkan perusahaan untuk menyusun Sustainability Report Peraturan satu-satunya mengenai laporan ini dikeluarkan oleh Otoritas Jasa Keuangan (OJK) melalui POJK No. 51 tanggal 27 Juli 2017 yang mewajibkan seluruh lembaga keuangan untuk menyusun dan melaporkan Sustainability Report sedangkan bagi perusahaan non lembaga keuangan, pengungkapan Sustainability Report masih bersifat sukarela (voluntary). Karena sifatnya yang sukarela, maka jumlah perusahaan yang mengungkapkan Sustainability Report masih terbatas. Tahun 2016, terdapat 49 perusahaan yang terdaftar di BEI menerbitkan Sustainability Report, dimana 37 perusahaan merupakan perusahaan yang bergerak di bidang non-keuangan, dan 12 perusahaan merupakan perusahaan yang bergerak di bidang keuangan (OJK, 2017).

Ada beberapa faktor yang menjadi motif mengapa perusahaan mengungkapkan Sustainability Report, diantaranya: ukuran (Daljono, 2013; Adila and Syofyan, 2016; Barung, Simanjuntak and Hutadjulu, 2018) kinerja keuangan (Khafid and Aniktia, 2015; Suryani and Wijayati, 2019), Good Corporate Governance (Khafid \& Aniktia, 2015; Barung, Simanjuntak \& Hutadjulu, 2018; Pitriasari \& Dewi, 2019), karakteristik perusahaan (Adila \& Syofyan, 2016), leverage (Khafid \& Aniktia, 2015). 
Penelitian ini akan berfokus kepada ukuran perusahaan dan kinerja keuangan sebagai faktor penentu perusahaan dalam mengungkapkan Sustainability Report. Dalam penelitian ini, ukuran perusahaan diukur dengan melihat total aset yang dimiliki oleh perusahaan (Adila \& Syofyan, 2016). Kinerja Keuangan akan diukur dengan menggunakan Profitabilitas dan leverage. Profitabilitas akan menggunakan indikator Return on Assets (ROA) (Pratama \& Yulianto, 2015). Sedangkan leverage menggunakan indikator Debt to Equity Ratio (DER) (Khafid \& Aniktia, 2015). Sedangkan pengungkapan Sustainability Report diukur dengan menggunakan Sustainability Report Disclosure Index (SRDI). Perhitungan SRDI dilakukaan dengan cara memberikan nilai 1 untuk setiap item yang diungkapkan dan memberi nilai 0 untuk setiap item yang tidak diungkapkan. Setelah diukur per item, perhitungan SRDI dapat dilakukan dengan cara membagi jumlah item yang diungkapkan perusahaan dengan jumlah item yang diharapkan (Fadhilah, 2018) .

\section{METODE PENELITIAN}

Penelitian ini menggunakan pendekatan deduktif. Populasi dalam penelitian ini adalah seluruh perusahaan sektor non-keuangan yang terdaftar di Bursa Efek Indonesia (BEI) tahun 20172018. Teknik pemilihan sampel menggunakan teknik purposive sampling, dengan kriteria sebagai berikut :

1. Perusahaan sektor non-keuangan yang terdaftar di Bursa Efek Indonesia (BEI) tahun 2017-2018.

2. Perusahaan yang mempublikasikan annual report dan Sustainability Report tahun 2017-2018.

3. Perusahaan yang menerbitkan Sustainability Report menggunakan GRI Standards.
Berdasarkan kriteria purposive sampling, didapatkan jumlah sampel sebanyak 42 sampel.

Keseluruhan sampel akan diolah dengan menggunakan analisis regresi linier berganda. Pengujian hipotesis dapat dilakukan dengan menggunakan persamaan berikut ini :

$$
\mathrm{Y}=\alpha+\beta 1 \mathrm{X} 1+\beta 2 \mathrm{X} 2+\beta 3 \mathrm{X} 3+\varepsilon
$$

Keterangan :

$$
\begin{aligned}
& \mathrm{Y}=\text { Pengungkapan Sustainability } \\
& \text { Report } \\
& \alpha=\text { Konstanta } \\
& \beta \quad=\text { Koefisien Regresi } \\
& \mathrm{X} 1=\text { Ukuran Perusahaan (Total } \\
& \text { Aset) } \\
& \mathrm{X} 2=\text { Profitabilitas (Return on } \\
& \text { Assets) } \\
& \mathrm{X} 3=\text { Leverage (Debt to Equity } \\
& \begin{array}{l}
\text { Ratio) } \\
\varepsilon=\text { Error term }
\end{array}
\end{aligned}
$$

\section{HASIL DAN PEMBAHASAN \\ Uji Asumsi Klasik}

Model regresi dalam penelitian dapat digunakan sebagai alat estimasi secara signifikan dan representatif jika data yang digunakan mempunyai kualitas yang tidak menyimpang dari asumsi dasar klasik regresi. Asumsi klasik ini meliputi uji normalitas, uji heterokedastisitas, uji multikolinearitas, dan uji autokorelasi.

\section{Uji Normalitas Data}

Hasil uji normalitas data menggunakan Kolmogorov-Smirnov Test menunjukkan nilai signifikansi dari model regresi ini adalah 0,200. Nilai signifikansi ini menunjukkan angka yang lebih besar dari tarif signifikansi nya yaitu $\geq 0,05$. Oleh karena itu, dapat ditarik kesimpulan bahwa penelitian ini memiliki data yang berdistribusi normal. 


\section{Uji Multikolinearitas}

Hasil uji multikolinearitas menunjukkan bahwa nilai tolerance X1 adalah $0,974, \mathrm{X} 2$ adalah 0,988 dan X3 adalah 0,986. Ketiga nilai tolerance untuk masing-masing variabel pada model regresi ini lebih dari 0,10 . Sementara itu pada model regresi juga memiliki nilai VIF kurang dari 10. Sehingga dapat ditarik kesimpulan bahwa model regresi penelitian ini tidak terjadi multikolinearitas.

\section{Uji Heteroskedastisitas}

Hasil uji heteroskedastisitas menunjukkan bahwa nilai signifikansi pada model regresi penelitian ini ditunjukan dengan nilai $\mathrm{X} 1$ sebesar 0,508, X2 0,667 dan X3 0,068 dimana ketiga nilai tersebut lebih besar dari 0,05 . Untuk itu dapat ditarik kesimpulan bahwa model regresi dalam penelitian ini tidak terjadi heteroskedastisitas.

\section{Uji Autokorelasi}

Hasil uji autokorelasi menunjukkan bahwa nilai signifikansi pada model regresi penelitian ini adalah sebesar 0,160 dimana lebih besar dari 0,05 , sehingga dapat ditarik kesimpulan bahwa model regresi dalam penelitian ini tidak terjadi gejala autokorelasi. Hasil pengujian asumsi klasik menyimpulkan bahwa model regresi dapat digunakan.

Tabel 1 Uji Regresi Linier Berganda

\begin{tabular}{lc}
\hline \multicolumn{1}{c}{ Variabel } & $\begin{array}{c}\text { Unstandardized } \\
\text { Coefficient }\end{array}$ \\
\hline Constant & 0,697 \\
\hline Ukuran Perusahaan & $-0,029$ \\
\hline Profitabilitas & $-0,317$ \\
\hline Leverage & $-0,004$ \\
\hline Sumber: Data Olahan SPSS (2020) \\
\multicolumn{2}{c}{ Berdasarkan tabel 1, maka } \\
model penelitian ini dapat dirumuskan \\
sebagai berikut:
\end{tabular}

$$
\begin{aligned}
\mathrm{Y}=0,697-0,029 & \text { SIZE } \\
& -0,317 \text { PROF } \\
& -0,004 \mathrm{LEV}
\end{aligned}
$$

Dari persamaan regresi yang telah disusun dapat diinterpretasikan sebagai berikut :

1. Nilai konstanta (a) dalam model regresi ini adalah sebesar 0,697. Nilai ini menunjukkan bahwa jika variabel-variabel independen dalam penelitian ini bernilai 0, maka nilai pengungkapan Sustainability Report adalah sebesar 0,697.

2. Nilai koefisien regresi variabel ukuran perusahaan (b1) dalam model regresi ini adalah sebesar $-0,029$. Nilai ini menunjukkan bahwa jika variabel-variabel independen lain bersifat konstan, maka setiap kenaikan 1 satuan ukuran perusahaan akan diikuti dengan penurunan pengungkapan Sustainability Report sebanyak 0,029 .

3. Nilai koefisien regresi variabel profitabilitas (b2) dalam model regresi ini adalah sebesar -0,317. Nilai ini mengindikasikan bahwa jika variabel independen lain bersifat konstan, maka setiap kenaikan 1 satuan profitabilitas akan diikuti dengan penurunan pengungkapan Sustainability Report sebanyak 0,317.

4. Nilai koefisien regresi variabel leverage (b3) adalah sebesar $-0,004$. Nilai ini mengindikasikan bahwa jika variabel independen lain bersifat konstan, maka setiap kenaikan 1 satuan leverage akan diikuti penurunan pengungkapan Sustainability Report sebanyak 0,004.

Tabel 2 Koefisien Determinasi Hipotesis

\begin{tabular}{cccc}
\hline$R$ & $R$ Square & $\begin{array}{c}\text { Adjusted } \\
R \text { Square }\end{array}$ & $\begin{array}{c}\text { Std Error } \\
\text { of } \\
\text { Estimaste }\end{array}$ \\
\hline 0,27 & 0,073 & $-0,001$ & 0,11303 \\
\hline Sumber: Data Olahan SPSS (2020)
\end{tabular}

Sumber: Data Olahan SPSS (2020) 
Nilai R Square menunjukan $7,3 \%$ yang berarti $7,3 \%$ variabel dependen yaitu pengungkapan Sustainability Report dapat dijelaskan oleh variabel independen yaitu ukuran perusahaan, profitabilitas, dan leverage. Sedangkan sisanya sebesar 92,7\% dijelaskan oleh faktor lain yang tidak disertakan dalam penelitian ini.

\section{Pengujian Hipotesis Secara Simultan}

Hasil uji $F$ statistik ditunjukan pada tabel 3 di bawah ini:

Tabel 3 Tabel Uji F

\begin{tabular}{llllll}
\hline Model & $\begin{array}{c}\text { Sum of } \\
\text { Square }\end{array}$ & df & $\begin{array}{c}\text { Mean } \\
\text { Square }\end{array}$ & F & Sig \\
\hline Regression & 0,038 & 3 & 0,013 & 0,992 & 0,407 \\
\hline Residual & 0,485 & 38 & 0,013 & & \\
\hline Total & 0,523 & 41 & & & \\
\hline
\end{tabular}

Sumber: Data Olahan SPSS (2020)

Dari tabel diatas dapat dilihat bahwa nilai signifikansi $\mathrm{F}$ model regresi dalam penelitian ini adalah sebesar 0,407 . Nilai signifikansi ini lebih besar dari 0,05 sehingga dapat disimpulkan bahwa variabel independen dalam model regresi yakni ukuran perusahaan, profitabilitas, dan leverage secara bersama-sama tidak berpengaruh terhadap variabel dependen yaitu pengungkapan Sustainability Report.

\section{Pengujian Hipotesis Secara Parsial}

Uji hipotesis dalam penelitian ini menggunakan uji $t$ statistik yang bertujuan untuk mengetahui seberapa jauh pengaruh variabel independen terhadap variabel dependen. Uji $t$ dilakukan dengan melihat $t$ hitung lalu dibandingkan dengan $t$ tabel. Uji t juga dapat dilakukan dengan cara melihat taraf signifikansi pada masing-masing variabel. Berdasarkan hasil pengolahan data, maka dapat diperoleh hasil sebagai berikut:
Tabel 4 Tabel Uji t

\begin{tabular}{lcc}
\hline Variabel & $\mathrm{t}$ & \multicolumn{1}{c}{ Sig } \\
\hline Ukuran Perusahaan & $-0,717$ & 0,478 \\
\hline Profitabilitas & $-1,612$ & 0,115 \\
\hline Leverage & $-0,212$ & 0,833 \\
\hline Sumber: Data Olahan SPSS (2020) &
\end{tabular}

Dari hasil pengujian statistik tabel 4, dapat dijabarkan sebagai berikut

1. Variabel ukuran perusahaan memiliki tanda negatif dengan nilai signifikansi sebesar 0,478 , sehingga nilai signifikansi $>0,05$. Dengan demikian dapat disimpulkan bahwa variabel ukuran perusahaan tidak berpengaruh terhadap pengungkapan Sustainability Report, maka $\mathrm{H}_{0}$ diterima dan $\mathrm{H}_{\mathrm{a}}$ ditolak.

2. Variabel profitabilitas memiliki tanda negatif dengan nilai signifikansi sebesar 0,115 , sehingga nilai signifikansi $>0,05$. Dengan demikian dapat disimpulkan bahwa variabel profitabilitas tidak berpengaruh terhadap pengungkapan Sustainability Report, maka $\mathrm{H}_{0}$ diterima dan $\mathrm{H}_{\mathrm{a}}$ ditolak.

3. Variabel leverage memiliki tanda negatif dengan nilai signifikansi sebesar 0,833, sehingga nilai signifikansi $>0,05$. Dengan demikian dapat disimpulkan bahwa variabel leverage tidak berpengaruh terhadap pengungkapan Sustainability Report maka $\mathrm{H}_{0}$ diterima dan $\mathrm{H}_{\mathrm{a}}$ ditolak.

\section{Pengaruh Ukuran Perusahaan Terhadap Pengungkapan \\ Sustainability Report}

Berdasarkan hasil uji hipotesis (uji t) dalam analisis statistik pada penelitian ini, menunjukkan bahwa secara parsial ukuran perusahaan tidak berpengaruh signifikan terhadap pengungkapan Sustainability Report. Artinya, besar atau kecilnya ukuran suatu perusahaan tidak mempengaruhi pengungkapan Sustainability Report. 
Hal ini terjadi karena ukuran perusahaan tidak menjadi landasan perusahaan untuk mengungkapkan informasi. Besar atau kecilnya perusahaan, sudah menjadi kewajiban bagi perusahaan untuk mengungkapkan informasi lingkungan dan sosialnya (Adila \& Syofyan, 2016).

Hasil penelitian ini sejalan dengan hasil peneltian yang dilakukan oleh (Adila \& Syofyan, (2016), (Liana, 2019) dan Nasir et al., (2014). Menurut Liana (2019) perusahaan kecil pun dapat mengungkapkan kegiatan tanggung jawab sosial perusahaannya dengan baik jika itu memang diperlukan dan pelaksanaan pengungkapan tanggung jawab sosial dianggap mampu memberikan keuntungan baik secara langsung maupun tidak langsung (dalam hal ini adalah kemampuan perusahaan untuk mempertahankan keberlanjutan aktivitas perusahaan) dan mendapatkan legitimasi usaha dari seluruh stakeholders.

\section{Pengaruh Kinerja Keuangan Perusahaan Terhadap Pengungkapan Sustainability Report}

Berdasarkan hasil uji hipotesis (uji t) dalam analisis statistik pada penelitian ini, menunjukkan bahwa secara parsial profitabilitas tidak berpengaruh signifikan terhadap pengungkapan Sustainability Report. Ini dikarenakan ketika perusahaan memiliki tingkat profitabilitas yang tinggi, manajer tidak perlu melaporkan hal-hal yang dapat mengganggu kepentingan perusahaan untuk mengalokasikan laba sebagai manajer tujuan minat. Ini memicu konflik agensi. Sebagai Teori Agensi, konflik agensi akan terjadi jika kepentingan manajer bertentangan dengan kepentingan pemangku kepentingan (Riantani \& Nurzamzam, 2015).
Hasil penelitian ini juga didukung dengan penelitian yang dilakukan oleh Khafid \& Aniktia, (2015) serta Riantani \& Nurzamzam, (2015). Perusahaan dengan profitabilitas yang lebih tinggi akan lebih mampu melakukan tanggung jawab sosial dan karenanya memiliki pengungkapan Sustainability Report lebih baik, namun disisi lain perusahaan juga dapat menghasilkan keuntungan dengan mengorbankan lingkungan sehingga menyebabkan minimnya pengungkapan. Berdasarkan pernyataan tersebut, perusahaan dengan profitabilitas tinggi bisa saja bersumber dari aktivitas perusahaan yang dapat berdampak buruk pada lingkungan dan masyarakat sehingga perusahaan cenderung untuk tidak melakukan pengungkapan sosial dan lingkungan (Khafid \&Aniktia, 2015).

Selain profitasbilitas, hasil uji hipotesis (uji t) dalam analisis statistik pada penelitian ini, menunjukkan bahwa secara parsial leverage tidak berpengaruh signifikan terhadap pengungkapan Sustainability Report. Semakin tinggi leverage perusahaan, semakin besar kemungkinan perusahaan akan melanggar perjanjian pinjaman, sehingga perusahaan akan mencoba melaporkan profit lebih tinggi, yang dapat menjadi salah satu cara untuk mengurangi biaya-biaya, termasuk biaya pengungkapan informasi sosial. Hal ini dikarenakan biaya untuk proses pembuatan laporan keberlanjutan cukup tinggi (Lucia \& Panggabean, 2018).

$$
\text { Hasil penelitian ini juga }
$$
didukung dengan penelitian yang dilakukan oleh Lucia \& Panggabean (2018). Hal ini terjadi karena saat ini banyak perusahaan yang sudah sadar akan kepentingan lingkungan dan sosial dan tidak hanya semata mencari keuntungan untuk perusahaan sendiri, sehingga tinggi rendahnya tingkat 
leverage tidak mempengaruhi pengungkapan tanggung jawab sosial.

\section{PENUTUP \\ Kesimpulan}

Berdasarkan penelitian yang telah dilakukan mengenai pengaruh ukuran perusahaan dan kinerja keuangan terhadap pengungkapan Sustainability Report pada perusahaan sektor non-keuangan yang terdaftar di Bursa Efek Indonesia (BEI) tahun 20172018, maka dapat ditarik kesimpulan sebagai berikut :

1. Ukuran Perusahaan tidak berpengaruh terhadap pengungkapan Sustainability Report pada perusahaan sektor nonkeuangan yang terdaftar di Bursa Efek Indonesia (BEI) tahun 20172018, sehingga hipotesis pertama dalam penelitian ini ditolak.

2. Profitabilitas tidak berpengaruh terhadap pengungkapan Sustainability Report pada perusahaan sektor non-keuangan yang terdaftar di Bursa Efek Indonesia (BEI) tahun 2017-2018, sehingga hipotesis kedua dalam penelitian ini ditolak.

3. Leverage tidak berpengaruh terhadap pengungkapan Sustainability Report pada perusahaan sektor non-keuangan yang terdaftar di Bursa Efek Indonesia (BEI) tahun 2017-2018, sehingga hipotesis ketiga dalam penelitian ini ditolak.

\section{Saran}

Pada bagian akhir penelitian ini, peneliti bermaksud mengajukan beberapa saran yang berkaitan dengan pembahasan yang telah dilakukan sebelumnya. Saran berikut ini berguna untuk melengkapi keterbatasan penelitian ini, antara lain :
1. Bagi Perusahaan. Peneliti menyarankan kepada perusahaan untuk lebih aktif dalam mengungkapkan tanggung jawab sosialnya dalam Sustainability Report.

2. Bagi Pemerintah. Peneliti menyarakan kepada pemerintah atau pembuat regulasi mengenai Sustainability Report untuk lebih menegaskan kembali aturan mengenai pengungkapan Sustainability Report, karena meskipun sudah ada aturan tertulis tetapi masih banyak perusahaan yang belum mengungkapkan Sustainability Report di Indonesia.

3. Bagi peneliti selanjutnya. Peneliti menyarankan kepada peneliti selanjutnya yang ingin meneliti topik yang sama yaitu Sustainability Report untuk menambah variabelvariabel independen lain yang diamati selain variabel ukuran perusahaan, profitabilitas, dan leverage. Selain itu, peneliti menyarankan untuk memperbesar ukuran sampel yaitu pada seluruh perusahaan baik keuangan maupun non-keuangan yang terdaftar di Bursa Efek Indonesia. Dan juga diharapkan bukan hanya perusahaan yang ada di Indonesia saja, tetapi juga perusahaan-perusahaan yang ada di negara lain.

\section{DAFTAR PUSTAKA}

Adila, W., \& Syofyan, E. (2016) Pengaruh Corporate Governance dan Karakteristik Perusahaan Terhadap Pengungkapan Sustainability Report: Studi Empiris pada Perusahaan yang Terdaftar di BEI tahun 20102014', Jurnal WR, 4(2), 777792. 
Barung, M., Simanjuntak, A., M., A. \& Hutadjulu, L., Y. (2018) Pengaruh Mekanisme Good Corporate Governance dan Ukuran Perusahaan terhadap Kualitas Pengungkapan Sustainability Report (Studi Empiris pada Seluruh Perusahaan yang Listing di Bursa Efek Indonesia Periode 2011-2016), Jurnal Akuntansi \& Keuangan Daerah, 13(November), 76-89.

Daljono, F., A. (2013) Pengaruh Kinerja Keuangan, Ukuran Perusahaan dan Corporate Governance terhadap Pengungkapan Sustainability Report', Pengaruh Kinerja Keuangan, Ukuran Perusahaan Dan Corporate Governance Terhadap Pengungkapan Sustainability Report, 3(1), 580589.

Fadhilah, R. (2018) Pengaruh Profitabilitas terhadap Pengungkapan Sustainability Report dengan Kepemilikan Manajerial Sebagai Variabel Moderating, Jurnal Ekobis Dewantara, 1(2), 25-36.

Farneti, F., \& Guthrie, J. (2009) Sustainability reporting by Australian public sector organisations : Why they report, Accounting Forum, 33(2), 8998.

Global Reporting Initiative (2019) About GRI. Available at: https://www.globalreporting.org/ Information/aboutgri/Pages/default.aspx (Accessed: 8 February 2020).
Gray, R. (2006) Social, environmental and sustainability reporting and organisational value creation?: Whose value? Whose creation?', Accounting, Auditing \& Accountability Journal, 19(6), 793-819.

Khafid, M., \& Aniktia, R. (2015) 'Pengaruh Mekaniseme Good Corporate Governance Dan Kinerja Keuangan Terhadap Pengungkapan Sustainability Report', Accounting Analysis Journal, 4(3), pp. 1-10.

Liana, S. (2019) 'Pengaruh Profitabilitas, Leverage, Ukuran Perusahaan, dan Dewan Komisaris Independen Terhadap Pengungkapan Sustainability Report', Jurnal Ekonomi \& Ekonomi Syariah, 2(2), 199208.

Lucia, L., \& Panggabean, R., R. (2018) 'the Effect of Firm , S Characteristic and Corporate Governance', Social Economics and Ecology International Journal, 2(1), 18-28.

Nasir. (2014) Pengaruh Karakteristik Perusahaan Dan Corporate Governance Terhadap Pengungkapan Sustainability Report Pada Perusahaan Lq45 Yang Terdaftar', Jurnal Ekonomi Universitas Riau, 22(01), 1-18.

Pérez-López, D., Moreno-Romero, A. and Barkemeyer, R. (2015) Exploring the Relationship between Sustainability Reporting and Sustainability Management Practices', Business Strategy and the Environment, 24(8), 720-734. 
Pitriasari, P. \& Dewi, I. P. (2019)

Pengaruh Good Corporate

Governance dan Ukuran

Perusahaan Terhadap

Pengungkapan Sustainability

Report', Jurnal Sains

Manajemen dan Akuntansi, 9(1), $137-160$.

Pratama, A., \& Yulianto, A. (2015) 'Faktor Keuangan dan Corporate Governance Sebagai Penentu Pengungkapan Sustainability Report', Accounting Analysis Journal, 4(2), 1-10. doi: 10.15294/aaj.v4i2.7863.

Riantani, S., \& Nurzamzam, H. (2015) 'Analysis of Company Size, Financial Leverage, and Profitability and Its Effect To Csr Disclosure', Jurnal Dinamika Manajemen, 6(2), 203-213. doi: 10.15294/jdm.v6i2.4308.

Suryani, R., \& Wijayati, F. (2019) Large Determinant of Greenhouse Gas Emissions Disclosure in Indonesia, Riset Akuntansi dan Keuangan Indonesia, 4(2), 101-117. doi: 10.23917/reaksi.v4i2.8545. 